\title{
PERFORMANCE ASSESSMENT BASED ON INTELLIGENT POWER MANAGEMENT FOR STANDALONE PV SYSTEM IN REMOTE AREA OF IBADAN, NIGERIA
}

\author{
Oyinkanola Lateef Adewale ${ }^{1 *}$, Sawal Hamid Bin MD Alli ${ }^{2}$, Fajemiroye Joseph Ademola ${ }^{1}$ \\ ${ }^{1}$ Physics department, The Polytechnic, Ibadan, Oyo state, Nigeria \\ ${ }^{2}$ Electrical and Electronic Engineering Department, Universiti Kebangsaan Malaysia, Selangor, Malaysia
}

To every system there is a boundary to its procedure, thus, a system operating at higher than its operating limit will decrease its lifespan and that can contribute to failure of the arrangement. This leads us to assessments and calculations of standalone PV- system component based on the field assessment and performances in an area in Ibadan, Nigeria. Using relevant formulae to calculate the requirement of each element that makes up the stand-alone PV-system. The battery as an essential component of the microgrid, battery life depends on both depth and rate of discharge. The resolutions of this report reflect the abused of components involves in the initiation of the system especially the battery. The paper suggested an intelligent system to take care of the excess loads at a particular time, which alsowill take into account priority of the appliances at the time in relation to the capacity and state of the battery to control the appliances.

Key words: PV-system, Intelligent system, Load, battery, Control and assessment

\section{INTRODUCTION}

There is a persistent problem encountering by most of the developing country related to use of generation and transmission of electric power. Many African countries have the potential of using renewable energy, especially solar energy for right investments in infrastructure. Nigeria is a country that have high solar radiation on a daily basis (between 12 and 15 in the north and 10 and 12 hours in the south). There is a need for solution to the constant power outage and accessibility by over $60 \%$ of Nigerians that are off grid to be connected with renewable energy and establishing island microgrid system [1] [2].

Solar energy is one of the endless unsoiled and prospective energy as a gift from nature among all other unconventional energy options but of zero use in Nigeria. Right away, most developed countries, centered and focus along the development of renewable energy[3] [4]. To make room for sustainability, it is necessary to perform the expert assessment of the resources for those involved and get discouraged due to the unbalanced instalment and calculation. Several circumstance led to challenges being experienced in the quality and efficiency of renewable energy usage in Africa that include lack of investment in the infrastructure, inadequate manpower to handle solar energy generation and storage capacity of the energy from the sun.

The battery is a very important device in solar energy due to the intermittent nature of the sunlight. There are several types of the storage element, but in most of the residential and commercial applications of the renewable energy, they are into $\mathrm{Pb}$-acid batteries, the reasons may be to the cost relatively lower thanthe others.
Charge and discharge of this battery are important issues linked to battery characteristic. The life of the battery depending on the average depth of discharge (DOD) which is the percentage of the rated capacity which utilized per cycle[5]. The deeper the discharge of a battery, the shorter it'slifespan. A battery in everyday function that is discharged to not more than $40 \%$ of its capacity should last for more than 3000 cycles and may not require a substitute for up to 12 years. A battery that frequently heavily discharges may last no longer than 2 years [6].

Instability occurs because of big demand and the routine of the contrivances in the system. The solution to the existing problems brings about energy efficiency, reliability; economic constraint by integration of renewable energy resources to restore the stability of the power system [7] [8]. Residential which sometimes carries up to half of the demand on the utility in some of the areas in grid-connected or standalone can be a focuson, in order to improve microgrid and most of the energyquality [9].

In modern day there are several technologies developed such as smart meter, home automation and various forms of the energy storage equipmentthat lead to the implementation of home, offices, and industries load and energy management [10][11][12][13].This paper, focusing on the residential load management for off-grid for smooth and encouragement to use renewable energy. For the past years, many research projects focused on demands side management and load control of smart grid technologies for different reasons. Nowadays, energy in the residential building accounts for close to $32 \%$ of the global total final energy use in the globe [14].

The main purpose of this study is to develop an intelligent system to determine the power consumption based 
on the SOCof the batteries using rule-based fuzzy logic control. Load management is instrument to provide information as per voltage level, current, and frequency which should be critically monitored to make sure that the system stability and reliability aremaintained[15]. The main goal is to avoid deep discharge of the battery in order to improve the batteries life so thaat cost of replacing the batteries will be reduce.

The remaining paper is ordered as follows: Section II gives the detail of the survey of the visited apartment. Section III description of the proposed control system. Result and discussion in section IV. In the end, the conclusion is given in section $\mathrm{V}$.

\section{SURVEY OF THE RESIDENTIAL USING PV SYSTEM}

In Oke-Odo, Apete, a suburb of Ibadan, South-west, Nigeria, is an area where there is a low level of electricity from the national grid. Mostly, those that can avoid it are used to standalone solar energy generation. A microgrid (standalone) is one of the promising system in electricity that can supply electrical energy, which usually obtained from solar energy. The system consists of the several groups of appliances as shown in Fig. 1. The content of the microgridis asolarpanel, as agenerator of energy, energy storage such as the battery and the group of loads that will draw the energy when they are connected.

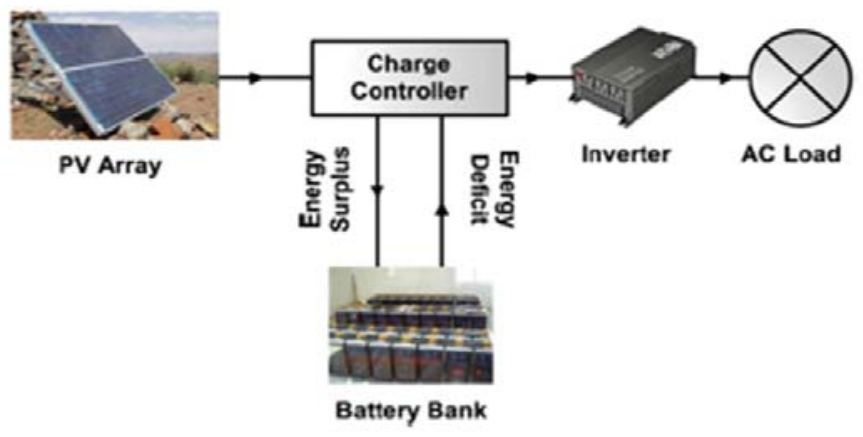

Figure 1: A complete system of the off-grid stand-alone system
Due to problem encounter by most owners of standalone, analysis of appliances and their power consumption in relation with state of charge of the battery is necessary. In addition, developan intelligent power management (IPM) to manage the operation of household appliances withthe state of the charge of the supply battery; it is indispensable to have a model that can simulate the behaviour of electric loads. Table 1 shows the components of the PV system used by the residents thatis takenas acase study in standalone system.

\section{Inverter capacity}

The inverter for the PV renewable energy system is an important device in running specific AC appliances. The modern inverter is extremely reliable and it is coming in several types, sizes, brands, and models. Choosing the best from such a long list can be a chore and there is no "best" inverter for all purposes. Power is usually the main factor. An inverter needs to meet two needs: peak, or surge-power, and continuous power. The inverter rated by their continuous wattage output.In terms of cost, thelarger they are, the more they cost. The inverter size is chosen so that its cost and inverter -related losses are minimized, i.e.it nominal power should be as small as possible, to provide high conversion efficiency during normal operation[16].

From the Table 2, the total power of the household is $2,495 \mathrm{~W}$, then due to a normal surge of fan and washing machine, the additional power of $1100 \mathrm{~W}$ at the start, making $3595 \mathrm{~W}$.

Table 1: PV System Component investigated (Case study)

\begin{tabular}{|l|c|c|c|}
\hline Components & Quantities & Capacity & Amount/Naira ( $)$ \\
\hline PV -array & 1 & $300 \mathrm{~W}$ & $60,000.00$ \\
\hline Battery & 1 & 100Ah & $75,000.00$ \\
\hline $\begin{array}{l}\text { Charge } \\
\text { controller }\end{array}$ & 1 & 30A,12V & $15,000.00$ \\
\hline Inverter & 1 & 1000W,12V & $45,000.00$ \\
\hline Total & & & 195,000 \\
\hline
\end{tabular}

Note: 1.00 US dollar $=304.55$ Nigerian Nairas (\#)

(as of Aug.2017; Sources: www.cb.gov.ng)

Table 2: Loads Table for the residential visited (Case study)

\begin{tabular}{|l||c|c|c|c|c|}
\hline Appliances & Consumption/W & Quantity & Duration & Time of the day & Power/day Wh/day \\
\hline \hline Television & 75 & 1 & 3 & Evening & 225 \\
\hline Radio & 40 & 1 & 2 & Morning & 80 \\
\hline \hline Lighting & 15 & 6 & 5 & Morning & 450 \\
\hline W/Machine & 500 & 1 & 1 & Evening & 500 \\
\hline Ceiling -fan & 50 & 2 & 3 & Evening & 300 \\
\hline Laptop & 60 & 2 & 5 & Morning/Evening & 300 \\
\hline Charging & 20 & 3 & 5 & Evening & 400 \\
\hline Side-Lamp & 20 & 4 & & & 2,495 \\
\hline Total & & & & & \\
\hline
\end{tabular}


Thus the capacity for an inverter to be used must be $3595 \mathrm{~W}$. But, looking at the components of the system in table 1 , the inverter used is of capacity $1000 \mathrm{~W}$ without considering the standby and efficiency rate of the inverter. Inverter perform better when running loads bellows 70 percent of its total capacity.

\section{Battery capacity}

The thing that determines the battery size in the standalone PV system is the number of loads, autonomy period, depth of discharge (DOD) and round-trip efficiency of the battery. For this type of battery used, i.e. deep -cycle battery is also known as valve gauge Lead -acid battery (VGLB) the DOD is $50 \%$ and round-trip efficiency is $75 \%$ with autonomy desire of 3 days. The calculationfor the depth of charge is given in equation (1) to (3).

\section{Total daily load Ah requirement $=$} (daily energy watt-hour )/(system nominal voltage)

Looking at the load requirement in Table 2 with $12 \mathrm{~V}$ battery, therefore,

\section{Total daily Ah requirement $=2,495 \mathrm{Wh} / 12 \mathrm{~V}=207.92 \mathrm{Ah} /$ day}

Require battery bank capacity $=$

(days of autonomy $\times$ daily load Ampere-hour)/(Battery DOD)

Require battery bank capacity $=$

$(3$ day $\times 207.92 A h /$ day $) /(0.75 \times 0.5)=623.76 \mathrm{Ah} / 0.375=$ 1,663.36 Ah

The average daily depth of discharge = total daily load Ampere-hour/total battery bank capacity $=$ 207.92 $A h / 1,663.36 A h=0.125=12.5 \%$
For deep circle battery generally one needs to design for $10-15 \%$ daily DOD[17]. Battery selection in most residential visited comprises of 12 V DC at 100 Ah capacity each.

Series/parallel configuration for the battery bank for greater voltage and current would be as described in Eq. (1) and (2). In the PV system, the source of energy to the system is solar array.Solar irradiation, solar cell temperature and the operating point of the PV system reflect the output of the of solar array. To have minimum PV-system output the area must fall within $1000-2000 \mathrm{Wh} / \mathrm{m} 2 \mathrm{as}$ minimum intensity and $150 \mathrm{C}$ as minimum temperature[18]. From the Fig.2, Nigeria divided into three zones with zone I receiving the highestirradiation as shown in the map, Ibadan $(7.430 \mathrm{~N}, 3.90 \mathrm{E})$ falls to zone III with irradiation between 4500 to $5000 \mathrm{Wh} / \mathrm{m} 2$ depending on the time of the year, accurate for good performance of PV application.

Total battery required $=1$ (series) $\times 17($ Parallel $)=17$

Battery Bank Capacity $(A h)=17($ Parallel $) \times 100 A h \approx 1700 A h$

\section{$P V$ - array requirement}

In the PV system, the source of energy to the system is solar array.Solar irradiation, solar cell temperature and the operating point of the PV system reflect the output of the of solar array. To have minimum PV-system output the area must fall within $1000-2000 \mathrm{Wh} / \mathrm{m} 2$ as minimum intensity and $150 \mathrm{C}$ as minimum temperature[18]. From the Fig.2, Nigeria divided into three zones with zone I receiving the highestirradiation as shown in the map, Ibadan $(7.430 \mathrm{~N}, 3.90 \mathrm{E})$ falls to zone III with irradiation between 4500 to $5000 \mathrm{Wh} / \mathrm{m} 2$ depending on the time

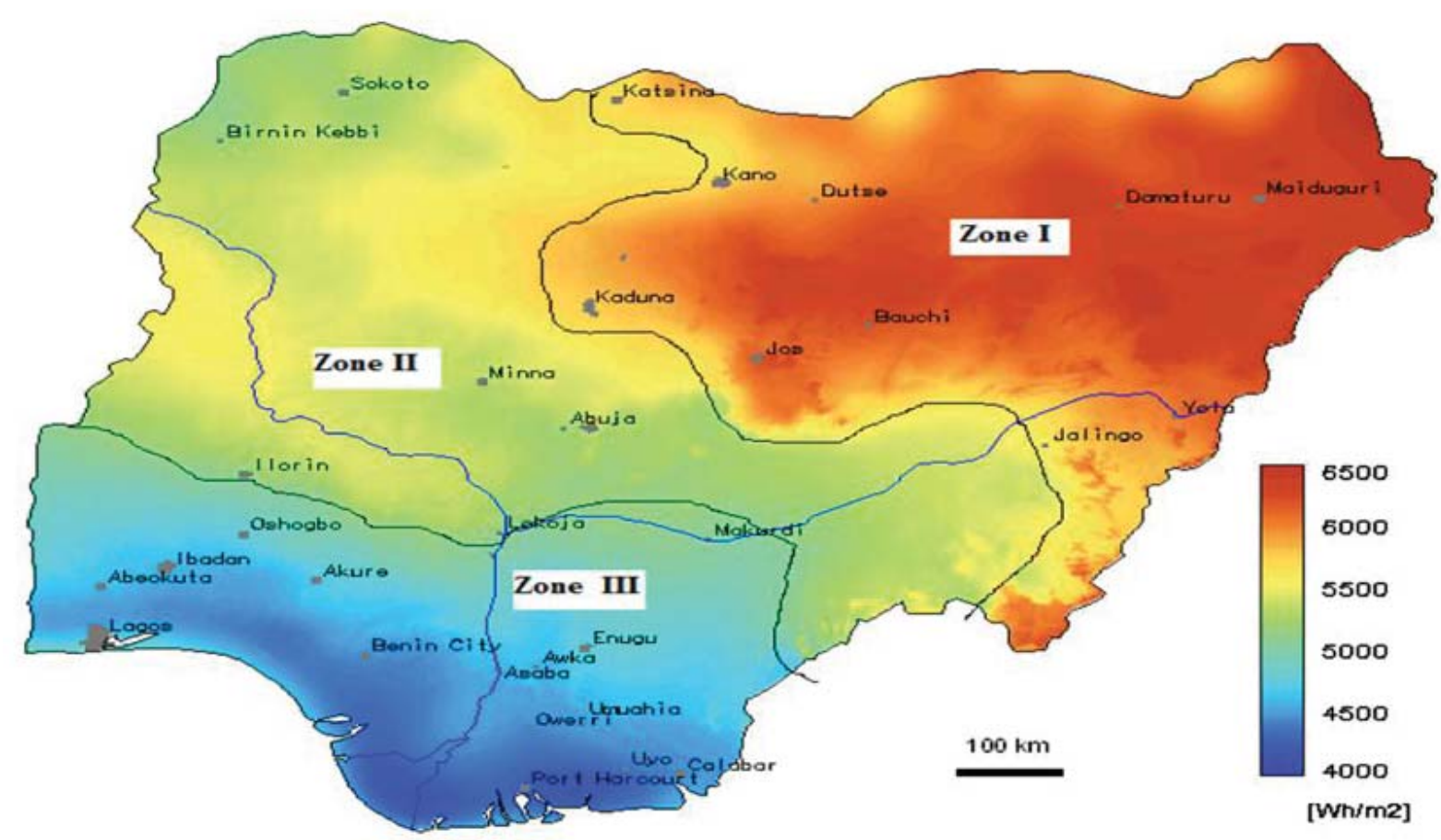

Figure 2: Solar Irradiation in Nigeria [19] 
of the year, accurate for good performance of PV application.

The following assumption was made during the month of January 2017 during sunshine hours. There must be anapproximations and values for some initial like load demand, PV loss, inverter loss, wire loss, andbattery loss, whichamount to their efficiency of their performance.

According to [20][21] the output energy of $P V \quad\left(E_{P V}\right)$ array can be given by Eq. (4):

$E_{P V}=A P V \times E s u n \times \eta_{P V}(t) \times \eta_{\text {inv }} \times \eta_{\text {wire }}$

Where

$A_{P V}$ is area of the PV module in $\left(\mathrm{m}^{2}\right)$

$E_{\text {sun }}$ is the hourly solar energy $\left(\mathrm{Wh} / \mathrm{m}^{2}\right)$,

$\eta_{P V}(t), \eta_{\text {inv }} \eta_{\text {wire }}$

represents the efficiency of the $\mathrm{PV}$, inverter and wire respectimely.

- Assume PV array temperature derate average of $15 \%$ daily requirement.

- Assume inverter losses at $10 \%$ of daily requirement.

- Assume fuses/disconnect losses at $1 \%$.

- Assume wiring losses at $3 \%$.

- Assume battery losses at $25 \%$.

- Total system losses are then $0.85 \times 0.9 \times 0.99 \times 0.97 \times 0.75=55 \%$.

- Adjusted system load requirement 207.92 Ah/day/0.55 = 378.04 Ah/day.

To select the PV module for the system (the module-derating factor is usually $80-90 \%$ ) for a rated peak current of $3.55 \mathrm{~A}$ and a rated peak voltage of $16.9 \mathrm{~V}$ at $300 \mathrm{~W}$.

By applied Eq. (5) and (6),

The number of parallel modules = (the adjusted load $\mathrm{Ah}$ requirement)/(module peak current xpeak sun-hours) $=378.04 \mathrm{Ah} / 3.55 \mathrm{~A} \times 6 \mathrm{~h}=$ 17.75

Meaning, 18 modules of $300 \mathrm{~W}$ in parallel.

The number of series modules $=$ (nominal system voltage)/(module peak voltage output $\times$ voltage temperature derate)

$=12 \mathrm{~V} /(16.9 \mathrm{~V} \times 85 \%)=0.84$

Total number of modules require

$=$ No. of modules in series $x$ No of modules in parallel

$=0.84 \times 17.75 \approx 15$ Modules

Numerical Battery energy sizing for the PV - System

Also, the energy storage capacity of the battery can be calculated using Eq.(7) according to [21]:
$E_{\text {bat }}=d_{O}\left(E_{\text {to }} / 8760\right) \quad 1 / \eta_{\text {batt }} \cdot 1 / D O D_{L}=d_{O} E_{h} / \eta_{\text {batt }} \cdot 1 / D O D_{L}$

where $d_{0}$ is the typical hours of energy autonomy, $E_{\text {tot }}$ is the annual energy of the load, $y_{\text {batt }}$ is the energy transformation efficiency, $\mathrm{DOD}_{\downarrow}$ is the maximum depth of discharge, and $E_{h}$ is the average hourly energy of the load. The relationship between the battery nominal output and input with the power of the PV (i.e. $P_{\text {bat in }}, P_{\text {bat out }}$ and $P_{P V}$ ) can be obtained usingEq. (8):

$P_{\text {bat_in }}=\gamma \cdot P_{\text {bat_out }} \leq P_{P V}$

where $y$ is representing the ratio of charge and discharge periods as well as the energy transformation efficiency in the battery. According to[22] " $\mathrm{V}$ " was assumed the value in the range of 1.5-3.0 for PV application.

Therefore, when the battery is in used the peak load that battery can be cover be represented and recognized the capacity factor of the load and the power efficiency as Eq.(9):

$\mathrm{P}_{\text {bat_out }}=\mathrm{T} \cdot \mathrm{E}_{\mathrm{h}} / \mathrm{CF}_{\text {load }} \cdot 1 / \eta_{\mathrm{p}}$

where the peak power percentage of the load the battery should cover, $\mathrm{CF}_{\text {load }}$ is the capacity factor and $\mathrm{y}_{\mathrm{p}}$ is the power efficiency.

\section{Determination of battery Energy}

Power demand by the Load (PLD) must be balanced with the power of the battery PB in order to have a good operating system (Assuming the battery is in autonomy). i.e.

$P_{B}=P_{L d}$

Energy discharge of the battery is given as shown by Eq. (11)

$E_{\text {Bat }}=\int_{0}^{T} P_{B} d t=\int_{0}^{T} V_{B} I_{B} d t$

where $V_{B}$ is the voltage, $I_{B}$ is the current and $P_{B}$ is the power of the battery.

\section{Determine state of the charge (SOC) of the battery}

The state of charge of the battery depends on the energy content of the battery in accordance with [23]:

$\% S O C=\left(1-\frac{1}{C} \int I_{B} d t\right) \times 100$

where $C$ is the capacity of the battery, and $I_{B}$ positive if the battery is discharged, and negative if battery is charging. Since $I_{B}$ be the current been drawn from the battery i.e. $I_{B}$ has influences on both $\mathrm{SOC}$ and the energy of the battery. 
Accordance with [5], the depth of charge (DOD) and the state of charge of the battery to give influence of the load i.e. current drawn from battery understanding the load on the battery.

$S O C=1-Q / C, \quad 0 \leq S O C \leq 1$

and

$D O D=1-S O C$

bat-

where $Q$ is the
tery capacity

Finally, the maximum and minimum SOC of the battery can be calculated as follows:

$S O C_{\text {min }}=S O C_{\text {max }}(1-D O D)$

This minimum SOC needs to be watched in other for the battery to be properly performed in accordance with its specification. To prevent the system from the abnormal situation and to assist the battery and the whole system we proposed an intelligent system to checkmate the system function and operation.

\section{PROPOSED INTELLIGENT POWER MANAGEMENT (IPM)}

The proposed IPM has the ability to switch off and on the appliances in the housed base on the condition of the battery in order to prevent the battery from discharge to the level of no-return. Unlike other smarts or load management that based their objective on the cost and peak load management. The system will use following criteria to control the system, the number of loads, the time of the day, the owner's comfort, and the level of the charge on the battery i.e. SOC accordance to Eq. (12).

In off-grid power management, the system consists of two control level: The input control and output control. The charge control/monitor serves as input control from the battery to monitor the state of charge (SOC) of battery:The function is to avoid over-discharging. The output control constitutes the predictive control of the load to measure the current of individual appliances to decide to be switched off based on battery level to avoid zero power output and prevent low discharge of the battery. Fig. 3 shows the flowchart of the IPM implimentation. The step in implementing the IPM is describe in following subsections:

Step A: The system power management algorithm begins with basic information about the appliances in the house:

- Reads the consumption of all appliances says fan, TV set, radio set, lighting in Watts.

- Measure the battery state of charge (SOC) level at specific time.

- Store each appliance priority setting for the leaning using Table 3 and 4.

- Check time of the day (Morning or Night)

- Schedule of the appliances into low or high consumption in accordance with their consumption at the particular time.
- Observe conditions of the battery within limit

40 $\leq \mathrm{SOC} \leq 100$.

- Specify the device status for all the electrical appliances to determine the current demand to SOC level.

- If demand is higher than SOC,then switch OFFsome appliances according to the level of the battery and priority of the appliance and go to step 5 .

Step B: The system using the algorithm to check for battery level SOC, the level of consumption of individual appliances and priority of each appliance at that specific time.For the battery level, the indicator will show the level of the battery and the amount of load it can bear.For consumption level, the algorithm we use current measurement to check the low or high consumption appliances. The determination to switch OFF/ON can now base on the priority at the particular time when the battery decreases to a certain SOC level fot it to set appropriate loads. The whole system then moves through the decision-making process to assure that all the criteria are met before appropriate appliances can be switched OFF to meet the capability of the battery.Since there is now total isolation from the PV, the battery is expected to charge back or continue on the level until is a chargeback to a higher point where all the appliances can go back to ON state.

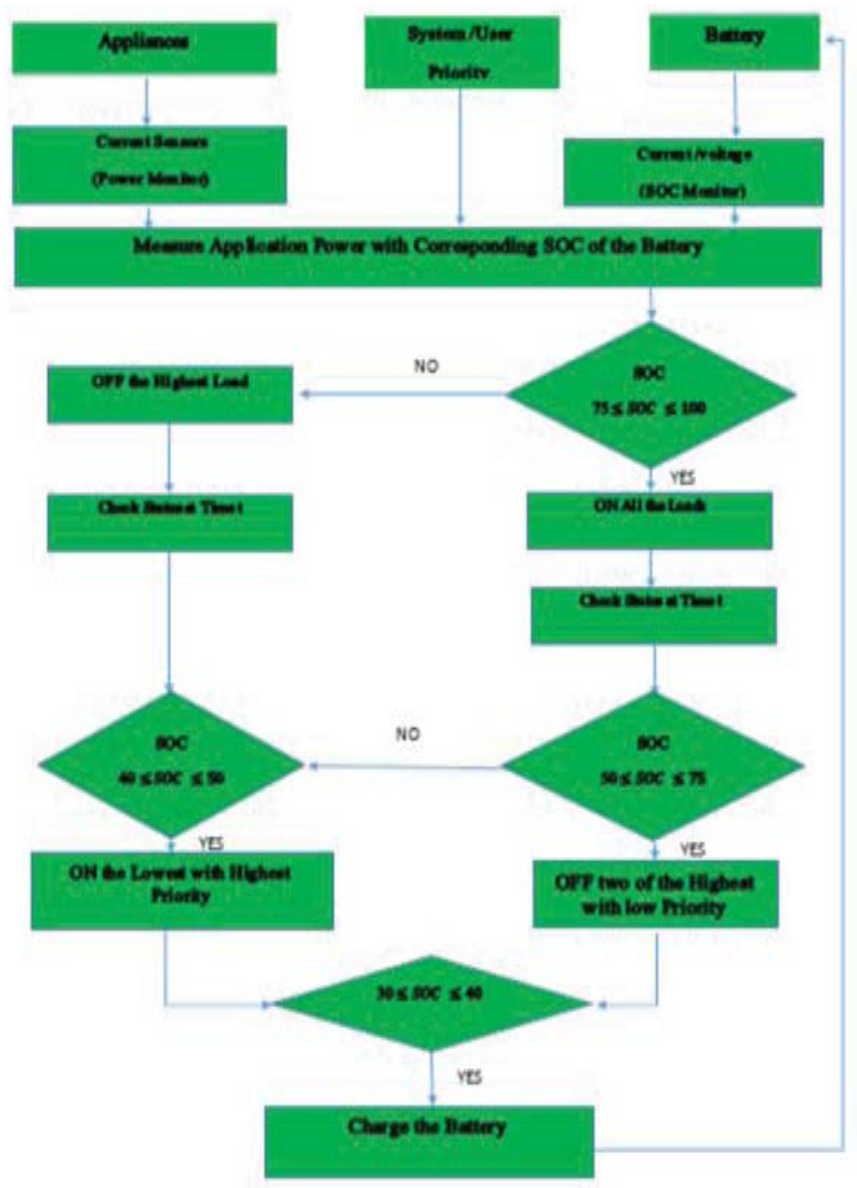

Figure 3: Flow Chart of the Intelligent Power Management (IPM) 
The battery monitor will send the amount of voltage on the battery to the control device unit fromtime to time in the form of state of charge (SOC). The control device unit receives the messages, recall past usage pattern of the appliances at that particular time and try to reschedule them in order of priority to minimize the output power. The demand proportional to the available power of the system i.e. SOC. The control unit decided to cut the highest load with less priority at that time. Meaning, the owner comfort, and priority are considered. In this way, the system will able to manage the available charge on the battery at that particular time until the charges or voltage increase.

When the charge of the battery has increased to an appropriate level, the system goes back to normal condition.

\section{RESULT AND DISCUSSION}

Questionnaires were distributed to the people in an Apete area of Ibadan using solar energy. This survey was conducted to assess the electric usage pattern of the household. An example of the results is shown in Table 1, 2 above and 3, 4 below.

Table 3: Load Priority Setting for decision making for Morning (4.00 a.m. -12.00 noon)

\begin{tabular}{|l||c|c|c|c|c|}
\hline Appliances & $\begin{array}{c}\text { Us- } \\
\text { age/ } \\
\text { Watt }\end{array}$ & Initial & Final & $\begin{array}{l}\text { Duration/ } \\
\text { Hour }\end{array}$ & $\begin{array}{l}\text { Priority/ } \\
\text { rank }\end{array}$ \\
\hline Light & 30 & 5.30 & 6.30 & 2.5 & 1 \\
\hline $\begin{array}{l}\text { Security } \\
\text { light }\end{array}$ & 60 & 4.00 & 6.30 & 2.5 & 2 \\
\hline Radio & 40 & 6.00 & 7.00 & 1 & 3 \\
\hline Lap Top & 60 & 5.00 & 6.00 & 1 & 4 \\
\hline $\begin{array}{l}\text { Charge } \\
\text { point }\end{array}$ & 60 & 5.30 & 7.00 & 1.5 & 5 \\
\hline Television & 75 & 6.30 & 7.00 & 0.5 & 6 \\
\hline Total & 325 & & & & \\
\hline
\end{tabular}

Table 5 depicts the priority of the appliances as owner request and time of the daytime, using Eqn. 1 to 6 confirm that most of the users are simply installed without proper documentation or rules for the installation. The capacity of the installed inverter, battery and PV-array are 1000 $\mathrm{W}, 100 \mathrm{Ah}, 300 \mathrm{~W}$ respectively against the calculated one of $3,595 \mathrm{~W}, 1700 \mathrm{Ah}$ and $1200 \mathrm{~W}$ respectively. This indicates that all the elements are not accurately connected.
Table 4: Load Priority Setting for decision making for Evening (12.00 noon -4.00 a.m.)

\begin{tabular}{|l|c|c|c|c|c|}
\hline Appliances & $\begin{array}{c}\text { Usage/ } \\
\text { Watt }\end{array}$ & Initial & Final & $\begin{array}{c}\text { Duration/ } \\
\text { Hour }\end{array}$ & $\begin{array}{c}\text { Priority/ } \\
\text { rank }\end{array}$ \\
\hline \hline Television & 75 & 6.00 & 10.00 & 4 & 1 \\
\hline $\begin{array}{l}\text { Charge } \\
\text { point }\end{array}$ & 60 & 5.30 & 10.00 & 4.5 & 2 \\
\hline Lap Top & 120 & 7.00 & 10.00 & 3 & 3 \\
\hline Radio & 40 & 6.00 & 8.00 & 2 & 4 \\
\hline Fan & 100 & 6.00 & 7.00 & 1 & 5 \\
\hline $\begin{array}{l}\text { Security } \\
\text { light }\end{array}$ & 60 & 7.00 & 4.00 & 2.5 & 6 \\
\hline $\begin{array}{l}\text { Washing } \\
\text { Machine }\end{array}$ & 500 & 7.00 & 8.00 & 1 & 7 \\
\hline Total & 995 & & & & \\
\hline
\end{tabular}

Table 5: Results

\begin{tabular}{|l|c|c|c|}
\hline Component & Case study & Condition & Calculation \\
\hline Inverter & $1000 \mathrm{~W}$ & $\begin{array}{l}\text { Continuous } \\
\text { Plus Surge }\end{array}$ & $\begin{array}{c}2,495 \mathrm{~W} \\
3,595 \mathrm{~W}\end{array}$ \\
\hline Battery & $100 \mathrm{Ah}$ & $\begin{array}{c}\text { Daily } \\
+3 \text { days }\end{array}$ & $\begin{array}{c}207.92 \mathrm{Ah} \\
1,700 \mathrm{Ah}\end{array}$ \\
\hline PV -array & $300 \mathrm{~W}$ & 15 Modules & $1200 \mathrm{~W}$ \\
\hline
\end{tabular}

Table 5 depicts the priority of the appliances as owner request and time of the daytime, using Eqn.1 to 6 confirm that most of the users are simply installed without proper documentation or rules for the installation. The capacity of the installed inverter, battery and PV-array are 1000 $\mathrm{W}, 100 \mathrm{Ah}, 300 \mathrm{~W}$ respectively against the calculated one of 3,595 W, 1700 Ah and $1200 \mathrm{~W}$ respectively. This indicates that all the elements are not accurately connected. Fig. 4shows the load profile of the apartment, which establishes that the load is higher in the early dawn and the evening time. The power consumption of the appliances such as Television, Laptop, radio, fan, light and washing machine is evaluated using current sensors and from the other side of the battery, the state of the batterywas measured. The proposed IPM performs switching off and on of the appliances based on the state of charge of the battery and time of the day. 


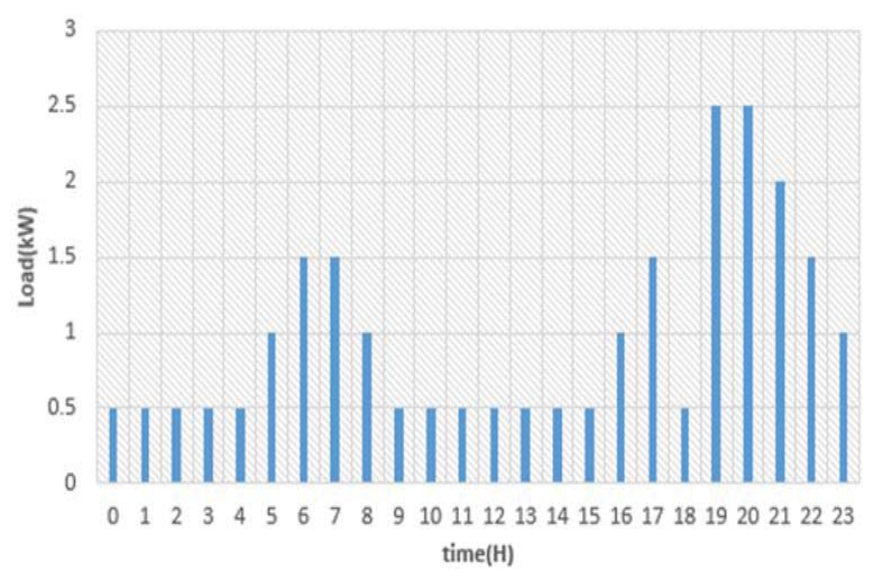

Figure 4: Load Profile of the Apartment under test

Fig.5 shows the output prototype of the intelligent power management (IPM) proposed which reflect the appliances to be monitor, the battery involves and the microcontroller that will be program based on the rule base and algorithm in Fig.3. To protect the battery from over-discharging, in order to prevent operation beyond the specified end-of-discharge voltage or current. When removing the load after discharge, the voltage of healthy battery gradually recovers and rises toward the nominal voltage. Then, IPM will serves as scheduling device for appropriate load to the charge on the battery.
Fig. 6 shows the comparison of the energy usage of the apartment with and without the IPM.This will lead into the low Loss of Load Probability (LLP). LLP reflects the proportion of the annual energy deficit to annual load demand. Because the IPM will extend the time of using the battery without reaching the point that canrender it incapable of holding charg anymore. The owner can endure a variety of pass- by when in the use of appliances that important at a particular time, but without contravening with the conformation of the supply and demand of the system. In addition, the PV panels were observed to be polycrystalline silicon panels that ordinary dust can affect the outcome of the product. The majority of the solar PV system is very poor quality because of cheaper importation as their labels are not fitting to their result. This also can affect the charging of the battery to require charges of the battery.

\section{CONCLUSION}

Many factors contribute to the useful life of a battery cell in a given application. These include the depth of discharge, discharge rate, cell temperature, charging regime, etc. Both battery and inverter suffer the most from unmanaged usage of PV system. Because to asses cost of storage system, the cost effectiveness of solar system is clearly reduce and one is risking a negative return if the application is not configured properly.

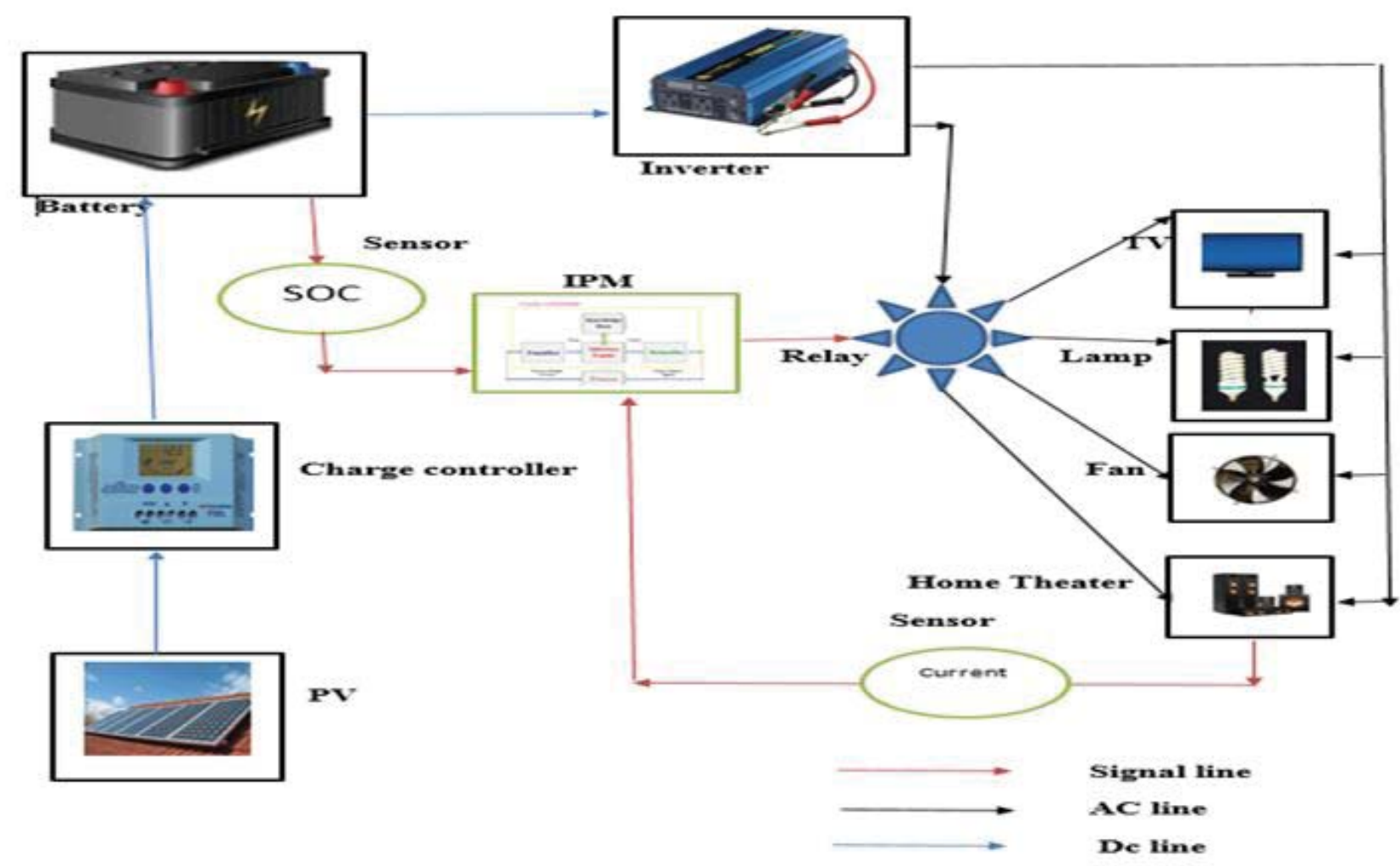

Figure 5: Schematic diagram of Intelligent Power Management(IPM) 


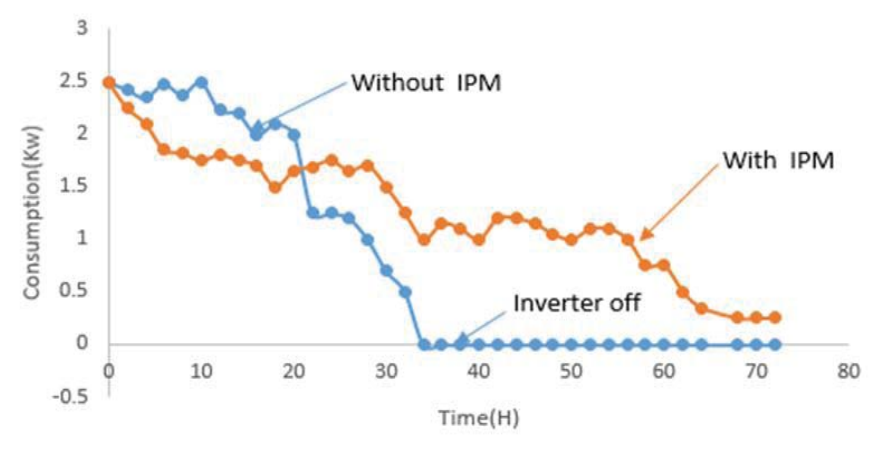

Figure 6: Energy consumption of the Apartment under test

Based on the findings of this work, it is recommended that an intelligent power managementcan beincluded to scheduling the appliances in order to keep the total household power demand below or balances with a capacity of the battery at a particular time of operation. Because greater loads require larger components and result in higher system cost. Once a battery selected to meet a given load, the power demanded by the load will determine by the depth and rate of discharge.Since DOD is one of those factors that influence the life prediction of the battery.

The Battery usually performs poorly whenever they are over discharge.A fully discharged battery is expected to take approximately 14 hours of direct sunlight to fully charge. The Addition of the control device will systematically select the loads based on their priority according to the content of the battery will suffice as the proper size of the battery to the loads. The new system will be included owner's comfort in addition to load priority. The benefit to the system also includes longer operating power without being stressed and extension of battery lifetime. The project will be a benefit to people in rural areas for them to install the PV- system within the requirement of the system.

\section{REFERENCES}

1. Saka, A. B., Olawumi, T. O. \& Omoboye, A. J., 'Solar Photovoltaic System: A Case Study of Akure, Nigeria', World Scientific News, 2017.

2. Tomonobu S, Toshiaki N, Katsumi U, and T. F, 'A hybrid power system using alternative energy facilities in isolated island', IEEE Transactions on Energy Conversion, vol. 20, no. 2, pp. 406-414, 2005.

3. Patra, S., Kishor, N., Mohanty, S. R., \& Ray, P. K, 'Power quality assessment in $3-\Phi$ grid connected PV system with single and dual stage circuits', International Journal of Electrical Power and Energy Systems, vol. 75, pp. 275-288, 2016.
4. Parlak, K., 'PV array reconfiguration method under partial shading conditions', International Journal of Electrical Power and Energy Systems, vol. 63, pp. 713-721, 2014.

5. David C C F, Marcos B K, Marcos RA M, and Antonio $M N$ L, 'Lifetime estimation technique for lead-acid batteries', IECON Proceedings (Industrial Electronics Conference), pp. 2076-2081, 2016.

6. Leadbetter, J., \& Swan, L. G., 'Selection of battery technology to support grid-integrated renewable electricity', Journal of Power Sources, vol. 216, pp. 376-386, Oct. 2012.

7. Bugaje, I. M., 'Renewable energy for sustainable development in Africa: A review', Renewable and Sustainable Energy Reviews, vol. 10, no. 6, pp. 603-612, 2006.

8. Safaai, N. S. M., Noor, Z. Z., Hashim, H., Ujang, Z., \& Talib, J., 'Projection of $\mathrm{CO} 2$ emissions in Malaysia', Environmental Progress \& Sustainable Energy, vol. 30, no. 4, pp. 658-665, Dec. 2011.

9. Ford, R., 'Reducing domestic energy consumption through behaviour modification', 2009.

10. Mubdir, B.,Mubdir, B., Al-Hindawi, A., \& Hadi, N., 'Design of Smart Home Energy Management System for Saving Energy', European Scientific Journal, vol. 12, no. 33, 2016.

11. Xiao, J., \& Boutaba, R. (2013)., 'The design and implementation of an energy-smart home in Korea', Journal of Computing Science and Engineering, vol. 7, no. 3, pp. 204-210, 2013.

12. Gomez, C., Magazine J., 'WHAN A Survey of Architectures and Technologies', IEEE Communications Magazine, pp. 92-110, 2010.

13. Maharjan, S., Zhu, Q., \& Zhang, Y., 'Demand Response Management in the Smart Grid in a Large Population Regime', Smart Grid, IEEE, vol. 7, no. 1, pp. 189-199, 2016.

14. Gesing F., 'The new Global Covenant of Mayors for Climate \&amp; Energy and the politics of municipal climate data', Zentra working papers in transnational studies, no. No.71/2017, 2017.

15. Wei, T., Kim, T., Park, S., Zhu, Q., Tan, S. X.-D., Chang, N., ... Maasoumy, M., 'Battery Management and Application for Energy-Efficient Buildings', in Proceedings of the The 51st Annual Design Automation Conference on Design Automation Conference - DAC '14, 2014, pp. 1-6.

16. Sangwongwanich, A., Yang, Y., Sera, D., Blaabjerg, F., \& Zhou, D., 'On the Impacts of PV Array Sizing on the Inverter Reliability and Lifetime', IEEE Transactions on Industry Applications, 2018. 
17. Chaurey, A. and Deambi, S., 'BATTERY STORAGE FOR PV POWER SYSTEMS : AN OVERVIEW', vol. 2, no. 3, pp. 227-235, 1992.

18. Mustapha, I., Dikwa, M. ., Musa, B. ., \& Abbagana, M. (2013)., 'Performance Evaluation of Polycrystalline Solar Photovoltaic Module in Wheather Conditions of Maiduguri, Nigeria', Arid Zone Journal of Engineering, technology and Environment, vol. 9, pp. 69-81.

19. Ohunakin, O. S., Adaramola, M. S., Oyewola, O. M., \& Fagbenle, R. O., 'Solar energy applications and development in Nigeria: Drivers and barriers', Renewable and Sustainable Energy Reviews, vol. 32, pp. 294-301, 2014.

20. Chineke, T. C., 'Equations for estimating global solar radiation in data sparse regions', Renewable Energy, vol. 33, no. 4, pp. 827-831, Apr. 2008.
21. Kazem, H. A., Khatib, T., \& Sopian, K., 'Sizing of a standalone photovoltaic/battery system at minimum cost for remote housing electrification in Sohar, Oman', Energy and building, vol. 61, pp. 108-115, 2013.

22. Kaldellis, J. K., Zafirakis, D., \& Kondili, E., 'Optimum sizing of photovoltaic-energy storage systems for autonomous small islands', International Journal of Electrical Power and Energy Systems, vol. 32, no. 1, pp. 24-36, 2010.

23. Ibrahim I., Khatib T., Muhamad A., 'Impact of Battery's Model Accuracy on Size Optimization Process of a Standalone Photovoltaic System', Sustainability. p. 8(9), 894; 2016. 